\title{
ISOLATION, MORPHOLOGICAL IDENTIFICATION AND PATHOGENICITY OF CYLINDROCLADIUM SCOPARIUM AND C. CLAVATUM ISOLATES OBTAINED FROM PLANTS RHIZOSPHERE CULTIVATED IN PERNAMBUCO STATE
}

\author{
Vitorina Nerivânia Covello Rehn'*; Maria Menezes ${ }^{1}$; Kurt Georg Rehn²; Rildo Sartori Barbosa Coêlho \\ ${ }^{1}$ Departamento de Agronomia, Universidade Federal Rural de Pernambuco, Recife, PE, Brasil; ${ }^{2}$ Departamento de Bioquímica, \\ Universidade Federal de Pernambuco, Recife, PE, Brasil
}

Submitted: August 20, 2003; Returned to authors for corrections: July 12, 2004; Approved: December 20, 2004

\section{SHORT COMMUNICATION}

\begin{abstract}
Twelve isolates of Cylindrocladium scoparium and 4 isolates of $C$. clavatum were obtained from the rhizosphere of various species of plants by baiting with Ricinus communis leaves. The isolates of C. scoparium developed conidia of 32-(45)-60 × 3 -(4)-5 $\mu \mathrm{m}$, and pyriform to ellipsoidal vesicles. $C$. clavatum showed conidia of 36-(44)-49 x 2-(4)-6 $\mu \mathrm{m}$ and clavate vesicles. All isolates induced necrosis on leaves and hypocotyls of eucalypt seedlings, with varying expression of symptoms.
\end{abstract}

Key words: Ricinus leaf bait, morphological markers, eucalyptus pathogenicity

The genus Cylindrocladium Morgan (teleomorph: Calonectria De Not) comprises species considered soil inhabitants that are saprophytes and facultative parasites, widespread in different environments all over the world (1). Typical symptoms caused by the pathogenic species are root rot, damping-off, wilt, leaf spotting, or necrotic lesions on fruits (7).

The purpose of the present study was to isolate species of Cylindrocladium from the rhizosphere of various plants by a baiting method, to identify them by morphological criteria and to check their pathogenicity on eucalypt seedlings under greenhouse conditions.

Small pieces of Ricinus communis L. leaves were disinfected (4), and placed upon soil samples of $20 \mathrm{~g}$ in sterile Petri dishes, collected from the rhizosphere of various plants (Table 1) and moistened with sterile distilled water (3). The baits were incubated for two days under alternating light at a temperature of $25^{\circ} \mathrm{C}$ and mycelia grown on the leaf segments were transferred to Petri dishes with PDA (Potato-Dextrose-Agar) to obtain pure cultures. For morphological identification, segments of disinfected Ricinus leaves were inoculated with plugs of $5 \mathrm{~mm}$ diameter from a young mold colony grown on PDA and leaves were kept in a Petri dish on a cotton swab moistened with sterile distilled water as above, until the formation of fruiting bodies. These were stained with Amann's blue (4) on microscope slides and observed under a light microscope. Of each isolate, average length and width of 20 conidia were determined with an ocular micrometer. Shape and septation of conidia were also considered, as well the shape of the vesicle $(1,2,7)$. Seedlings of eucalypt (Eucalyptus citriodora), 40 days after germination, were inoculated on both hypocotyls and leaves. Plugs as above were placed upon a slight incision in hypocotyls and fixed with Scotch tape. With leaves, the plug was put on the upper surface without wounding. Following inoculation, the plants were incubated for $48 \mathrm{~h}$ in a moist chamber at a temperature of $25^{\circ} \mathrm{C}$. The experiment was completely randomized using three replications in each treatment. The size of the lesions was measured four days after the inoculation. These data were subjected to Duncan's test, comparing means at a 5\% level of significance.

*Corresponding author. Mailing address: Departamento de Agronomia, Área de Fitossanidade, Universidade Federal Rural de Pernambuco, Av. Dom Manoel de Medeiros, S/N, Dois Irmãos, 52171-030, Recife, PE, Brasil. Tel.: (+5581) 3302-1209, Fax. (+5581) 3441-1711. E-mail: vickrehn@yahoo.com 
Table 1. Isolates, hosts, size of conidia and lesions ( $\mathrm{mm}$ ) induced by Cylindrocladium scoparium (Cs) and Cylindrocladium clavatum (Cc) on hypocotyls and on leaves of eucalypt (Eucalyptus citriodora Hook) plants, two days after to inoculation.

\begin{tabular}{|c|c|c|c|c|}
\hline \multirow{2}{*}{ Isolates/ host } & \multicolumn{2}{|c|}{ Size of conidia $(\mu \mathrm{m})^{1}$} & \multicolumn{2}{|c|}{ Pathogenicity $^{2}$} \\
\hline & Length & Width & Hypocotyl lesion & Leaf lesion \\
\hline \multicolumn{5}{|l|}{ C. scoparium $(\mathrm{Cs})$} \\
\hline Cs-Ara.1/ Annona crassiflora Mart. & $33-(45)-59$ & $3-(4)-5$ & $19.66 \mathrm{a}$ & 17.61ab \\
\hline Cs-Ara.2/ A. crassiflora & $33-(47)-60$ & $3-(4)-5$ & $18.30 \mathrm{a}$ & $24.67 \mathrm{a}$ \\
\hline Cs-Hel.3/ Heliconia sp. & $32-(44)-57$ & 3-(4)-4 & 18.16a & $9.97 \mathrm{bc}$ \\
\hline Cs-Pim.4/ Capsicum аппиит L. & $37-(45)-58$ & $3-(4)-5$ & $17.15 \mathrm{a}$ & 14.49abc \\
\hline Cs-Euc.5/ Eucalyptus citriodora Hook & $32-(46)-59$ & $3-(4)-5$ & $16.92 \mathrm{ab}$ & $29.32 \mathrm{a}$ \\
\hline Cs-Euc.6/ E. citriodora & $32-(44)-59$ & $3-(4)-4$ & $16.92 \mathrm{ab}$ & $25.36 \mathrm{a}$ \\
\hline Cs-Euc.7/ E. citriodora & $32-(48)-57$ & $3-(4)-5$ & $15.72 \mathrm{ab}$ & $9.02 \mathrm{bc}$ \\
\hline Cs-Euc.8/ E. citriodora & $34-(45)-60$ & $3-(4)-5$ & $15.62 \mathrm{ab}$ & $13.28 \mathrm{abc}$ \\
\hline Cs-Pin.10/ Pinus caribaea var. hondurensis Barret \& Golfari & $33-(46)-59$ & $3-(4)-5$ & 15.30ab & $14.77 \mathrm{abc}$ \\
\hline Cs-Pin.11/ Pinus caribaea var. hondurensis & $33-(45)-58$ & 3-(4)-4 & $14.93 \mathrm{ab}$ & $16.28 \mathrm{abc}$ \\
\hline Cs-Pin.12/ Pinus caribaea var. hondurensis & $33-(46)-58$ & 3-(4)-4 & $13.63 \mathrm{ab}$ & $26.22 \mathrm{a}$ \\
\hline $\begin{array}{l}\text { Cs-Pin.13/ Pinus caribaea var. hondurensis } \\
\text { C. clavatum }(\mathrm{Cc})\end{array}$ & $33-(45)-58$ & $3-(4)-5$ & $12.52 \mathrm{ab}$ & $24.96 \mathrm{a}$ \\
\hline Cc-Euc.9/ E. citriodora & $38-(45)-48$ & $3-(4)-6$ & $17.94 \mathrm{a}$ & $7.57 \mathrm{bc}$ \\
\hline Cc-Pin.14/ Pinus caribaea var. hondurensis & $37-(45)-47$ & $3-(4)-5$ & $14.55 \mathrm{ab}$ & $6.69 \mathrm{c}$ \\
\hline Cc-Cel.15/ Pennisetum purpureum Schumacher & 37-(44)-49 & $2-(3)-6$ & $10.62 \mathrm{~b}$ & $7.66 \mathrm{bc}$ \\
\hline Cc-Uru.16/ Bixa orellana L. & $36-(43)-48$ & $3-(4)-6$ & $10.62 \mathrm{~b}$ & $6.88 \mathrm{c}$ \\
\hline C.V. $(\%)$ & & & 8.03 & 15.66 \\
\hline
\end{tabular}

${ }^{1}$ Means $(\bar{\chi})$ of 20 conidia from each isolate cultivated on castor bean leaves. (Min.) Minimum and (Max.) maximum values are also shown;

${ }^{2}$ Date are $\log (\mathrm{x}+1)$ tranforms. Means of three replications;

Means followed by the same letter (vertical) are not signicantly different Ducan's test at $5 \%$.

Baits of Ricinus leaves as described permitted to obtain in high yield, 16 isolates of Cylindrocladium. This method was introduced by Orrego Fuente et al. (6), who used three different baits, but Ricinus leaves gave the best results.

From 16 isolates obtained, 12 were identified as Cylindrocladium scoparium (Cs), and four as C. clavatum $(\mathrm{Cc})$. Conidial lengths of $C$. scoparium varied between extremes of 32-60 $\mu \mathrm{m}$, and C. clavatum 37-49 $\mu \mathrm{m}$ (Table 1). Crous and Wingfield (1) found a higher range (40-66 $\mu \mathrm{m})$ for $C$. scoparium cultured on CLA (Carnation Leaf Agar), and Moreira et al. (5) reported a lower range (24.5-43.5 $\mu \mathrm{m})$ for this specie grown on Ricinus leaves. For C. clavatum, there were also small differences between the sizes of conidia observed and those cited by other researchers $(1,7)$. However, the data of Hodges and May (2) were identical to the values described here. The width of conidia was much alike in both species and the mean of $4 \mu \mathrm{m}$ was equal for all isolates except $\mathrm{Cc}-\mathrm{Cel} .15$ that seemed slightly slimmer. A similar value was reported by others $(1,2,5)$.

The species $C$. scoparium displayed hyaline and septate hyphae, conidiophores with di- or trichotomic branches composing phialides which vary between doliiform and reniform, and a septate stipe with a pyriform or ellipsoidal vesicle in the apical end; the conidia were cylindrical with rounded ends, hyaline and bicelular. The colony grown on PDA was typically light brown with a white border and a slightly irregular margin (Fig. 1A). C. clavatum showed the same features of hyphae, conidiophores and conidia as the other species; but had a clavate vesicle on an also hyaline septate stipe. C. scoparium formed on PDA a colony with a dark brown center and an irregular white border (Fig. 1B). Both species developed also microsclerotia, but the production of these resistant structures and the spatial arrangement of the cells in their interior are inadequate for taxonomy (1).

With eucalypt seedlings inoculated on hypocotyls or on leaves, all isolates of Cylindrocladium were pathogenic (Figs. $1 \mathrm{C}, \mathrm{D})$, but not in the same degree. Cs-Ara.1 caused wilt as well as collapse of the three target plants tested $48 \mathrm{~h}$ after their inoculation and could thus be considered as the most aggressive isolate, although its hypocotyl lesions did not look different from the other isolates (Table 1). Patent pathology was seen at least in two of three replications of the other isolates, after $96 \mathrm{~h}$ of incubation, with exception of Cc-Pin.14 and Cc-Uru.16, which 

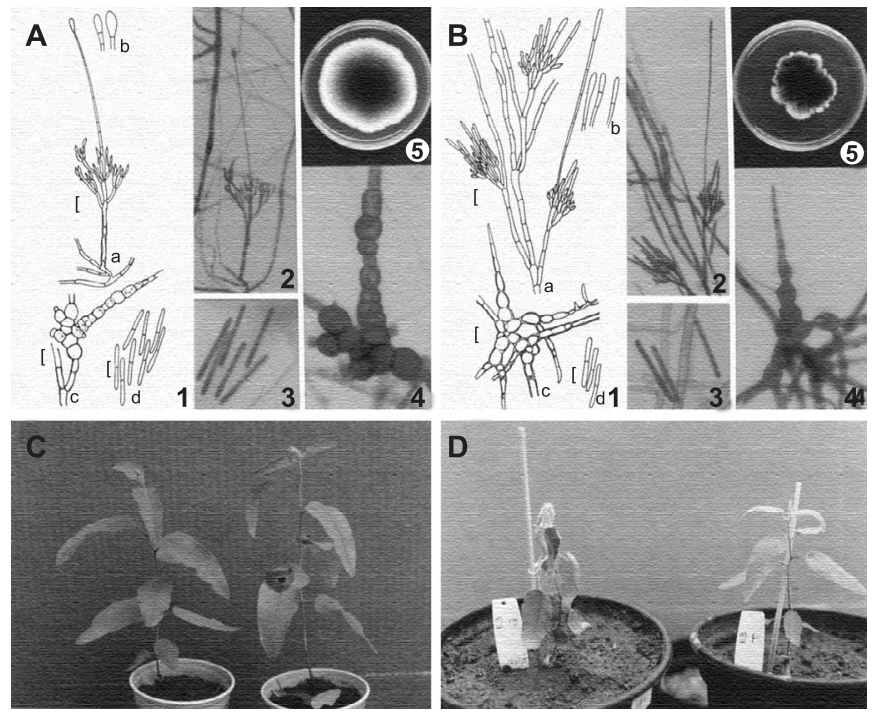

Figure 1. A - Cylindrocladium scoparium. 1-Schematic structures: (a) conidiophore; (b) vesicles; (c) microsclerotia; (d) conidia; length marker, $5 \mu \mathrm{m} ; 2$, 3, 4-Microscopic aspects. 5Colony. B - Cylindrocladium clavatum. 1-Schematic structures: (a) conidiophore; (b) vesicles; (c) microsclerotia; (d) conidia; length marker, $5 \mu \mathrm{m} ; 2$, 3, 4-Microscopic aspects. 5-Colony. Aspect of lesions symptoms on leaves (C), and wilt symptom (D) on Eucalyptus citriodora Hook plants induced by $C$. scoparium after 72 hours.

induced only modest necrosis in the hypocotyl without any collapse of plants. Reproductive structures of the pathogen could be detected in only one of the lesions produced by Cc-Pin.14 and Cc-Uru.16, respectively. The isolates of $C$. clavatum were generally less aggressive to eucalypt plants than $C$. scoparium, although Cc-Euc. 9 came from a eucalypt rhizosphere.

C. scoparium was reported to cause wilt, collapse and death in all plants of Eucalyptus camandulensis Denh., six days after inoculation (6). Hodges and May (2) found C. clavatum preferentially on Pinus sp., in spite of its many other possible host plants.

\section{RESUMO}

Isolamento, identificação morfológica e patogenicidade de isolados de Cylindrocladium scoparium e

C. clavatum da rizosfera de plantas cultivadas no Estado de Pernambuco

Doze isolados de Cylindrocladium scoparium e 4 isolados de C. clavatum foram obtidos da rizosfera de diversas plantas usando folhas de Ricinus communis como isca. A primeira espécie mostrou conídios com dimensões de 32-(45)-60 x 3 -(4)$5 \mu \mathrm{m}$ e vesícula piriforme a elipsoidal. Os conídios de $C$. clavatum apresentaram dimensões entre 36-(44)-49 x 2-(4)-6 $\mu \mathrm{m}$ e vesícula clavada. Em plântulas de eucalipto todos os isolados induziram necrose em folhas e hipocótilos, variando apenas na expressão dos sintomas.

Palavras-chave: isca de Ricinus, marcadores morfológicos, patogenicidade em eucalipto

\section{REFERENCES}

1. Crous, P.W.; Wingfield, M.J. A monograph of Cylindrocladium, including anamorphs of Calonectria. Mycotaxon, 51:341-435, 1994.

2. Hodges, C.S.; May, L.C. A root disease of pine, araucaria, and eucalyptus in Brazil caused by a new species of Cylindrocladium. Phytopathology, 62:898-901, 1972.

3. Linderman, R.G. Isolation of Cylindrocladium from soil infected azalea stems with azalea leaf traps. Phytopathology, 62:736-739, 1972.

4. Menezes, M.; Silva-Hanlin, D.M.W. Guia prático para fungos fitopatogênicos. Recife: UFRPE Imprensa Universitária, 1997. $106 \mathrm{p}$.

5. Moreira, A.M.; Alfenas, A.C.; Regazzi, A.J. Efeito do substrato e da cultura sobre o formato da vesícula, número de septos e dimensões de conídios de Cylindrocladium spp. Fitopatol. Bras., 16:54-59, 1991.

6. Orrego Fuente, A.L.; Menezes, M.; Oliveira, S.M.A.; Coelho, R.S.B. Análise comparativa de caracteres patogênicos e fisio-morfológicos para identificação de espécies de Cylindrocladium. Summa Phytopathol., 22:127-133, 1996.

7. Peerally, A. The classification and phytopathology of Cylindrocladium species. Mycotaxon, 60:323-366, 1991. 